\title{
SUSTAINABLE DEVELOPMENT IN AGRICULTURAL SECTOR IN SANGLI DISTRICT
}

\author{
*Vishal R. Patil and Ratan V. Hajare \\ * Research Students of Department of Geography, Shivaji University, Kolhapur. \\ ** Assistant Professor and Head, Department of Geography, Elphinstone Collage, Mumbai.
}

\begin{abstract}
:
Agriculture is the largest private sector and it enjoys a very important position in India economy the system of India for example Production processing, marketing etc. It has power to continuous changes in the region. This paper is aim to study the significance of sustainable development in the agricultural field. This study is based on the secondary data. Agriculture is the prime occupation of the peoples in country. Large amount of peoples from the rural areas having agriculture as their livelihood sustainable development in the agriculture sector aims to increase the productivity, efficiency and level of employment and further aims to protect and preserve the nature resources by the over utilization. It also guide to reduce soil degradation through multiple cropping system and through the deforestation and on any another reasons.
\end{abstract}

Keywords: Sustainable Development, Agriculture, Productivity, Ecology etc.

\section{INTRODUCTION:}

Being the largest private sector and it enjoys a very important position in India economy the agriculture system of India influence on the every sectors of India example production, processing, marketing etc. Gross Domestic Product (GDP) is the medium to analyses the role of agriculture in developing an economy. The agricultural development also contributes to the sustainable development of that region. The natural resources of the region are contributes to the sustainable agricultural development. The study area have two third of the population lives in the rural areas, having agricultural as their livelihood. In few time of spell there is large fall in agricultural because of the fast urbanization which is not good sign for agriculture and economy.

The productivity of agricultural sector improved by two ways firstly it can increase by output by efficiently utilizing the available resources and secondary output can be increased by variation of input in a district like sangli productivity is most important to satisfy the need of the people as we have a large population.

There are some categories through which agriculture can be studied as Traditional
Agricultural system, Modern Agricultural system and Sustainable Agricultural system

There is large efforts needed to produce the agriculture to a level where it is least affected by the irritable monsoon and needs little from outside the farm i.e. lesser dependence on chemical fertilizers and waste.

\section{Objective of the study:-}

- To analyses the extent of sustainable development in the agricultural sector in sangli.

- To evaluate the performance of agricultural sector as a part of Gross Domestic Product (GDP) in sangli Districts.

- To analyze the effect sustainable development on production policy in agricultural sector in sangli District.

\section{Significance of the Study:}

This paper aims to study the extent and importance of sustainable development its impact and effect on the agricultural practices in sangli district and how the production polices are changing in accordance with changing scenario.

\section{Study Region:}


Sangli district is one of the southernmost district of Maharashtra state It is located between the latitude of $16^{\circ} 45^{\prime \prime} \mathrm{N}$ and $17^{\circ} 33^{\prime \prime N}$ and the longitudes of $16^{\circ} 45^{\prime \prime} \mathrm{E}$ and $75^{\circ} 41^{\prime \prime} \mathrm{E}$. This district extended east-west about $205 \mathrm{~km}$ and north-south distance it extended $96 \mathrm{~km}$. District located 553 meter above mean sea level (AMSL). The total area of district according to the 2011 census is 861065 hectors. According to 2011 population is about 2820575.On the basis of Landscape, Climate and Rainfall the district can be divided into three broad Physiographic divisions The average rainfall of the district is $498.5 \mathrm{~mm}$ and the highest rainfall at Shirala and it goes decreasing towards eastern part.

\section{Data collection Method:}

This research paper is purely based on the secondary data. The secondary data will be gathered from District agricultural office and also gotten from different websites and internet etc. There is no empirical touch to this paper.

\section{Limitations of the Study:}

This study region comprises four tahasils which are largely affected by the drought pron conditions. So some time the conclusion and application of this research work is not in favour of some tehasils and this paper is puarly based on the secondary data.

\section{Sustainable Agricultural Development:}

The three broad areas farming system through which the issue of sustainable development can be studied. That consist traditional agricultural system, modern agricultural system and sustainable agricultural system. These can compare by economic, ecological and agricultural productive sustainability.

\section{Economic Sustainability:}

To make the agricultural sector sustainable it should be long lasting over period. Many times the government also tries to gain the production of such products, the prime aim behind that is export. But it's not good strategies because export of the products involves lots of costs like, packing, transportation, various taxes and custom duties of importer countries etc. and beside all this it include despite earnings. So the production is not to be export oriented only. It should be domestics supply oriented.

In the rural areas agriculture is main source of employment. It might be focused on specialization of the skills; it helps to enhance the production as well as efficiency level of agricultural products. It is an illusion that by producing the specific commodity production will contribute to earn more. The good quality products of developed countries are demanded more because of the low prize. Sustainable development of agriculture tries to accomplish this objective through the production of quality and environment friendly product.

\section{Ecological Sustainability:}

Lots of the agricultural traditional practiced which are not ecologically sustainable because at many times they are responsible for the soil erosion, reducing soil fertility and not proper use of natural resources. The sustainable development in agricultural sector has come up to with major advantages to reduce the effect of these causes.

The agricultural sector is facing the major problem of the soil erosion. This can be solved by the sustainable development. This can be solved by the sustainable development.

Large amount of the fresh water is utilized in the irrigation system, fertilizers as well as pesticides. It includes both surface and ground water.

Sustainable agricultural development makes easy to increase the quality of upper layer soil. By facilitating to restore and retain the rain water.

The concept of mixed cropping was introduced, by which diversity of crops are 
increased it also can be produced and raising the diversity of insects, other animals and plants in around fields. Sustainable development makes easier to utilize the available natural resources at optimum level.

The ecology is totally affected by the fertilizers chemicals and pesticides. They also put impact on population. Many types' health problems are emerged because of the improper use and storage of the pesticides. Sustainable development of agriculture reduces the use of harmful control pests and chemicals.

At present, the land is over utilized because of multiple cropping patterns. This over utilization leads to the soil degradation and loss in productivity. It also causes the decrease in quality of soil. This serious issue can be carefully handled by the sustainable agriculture development.

\section{Productive Sustainability:}

The sustainable development aims at increasing the productivity as well as increasing the level of food security in district. Development is meaningless if it is not able to fulfill the demand. Productive sustainability deals with the agricultural productivity of various crops and fulfills the minimum needs of the population. Many advanced and modern techniques and equipment's are failed because their limitation likes complexities in use, size of the land and are not easily accessible to poor farmers.

\section{CONCLUSION :}

India like rapid population growing country the practice of sustainable agriculture as well as study region is of most significance as it raises the yield, productivity, service, efficiency and helps to reduce the burden of the soil, water resources and degradation of other natural resources.

Sustainable development in agriculture targets to accepting specialization and using environment friendly techniques to protect and preserve the environment as well as to improve the level of production without damaging to the environment.

The improvement of sangli district in agriculture sector is in positive way over the years. Even with of many challenges like urbanization, progress in secondary sector etc. agriculture of sangli district reached a substantial growth, due to improve in irrigation facilities, use variety of fertilizers, HYV seeds, improvement in different projects, transportation facilities, electricity supply to agriculture sector and government subsidies.

\section{REFERANCE :}

Socio economic Abstract of Sangli District, 2016-17. Krishna H. Shukla and Nitin U. Dwivedi (2015), Sustainable development in agricultural sector in India, The Business \& Management Review, Volume 5, Page 221-222.

Dr. Deepashree (2010), Indian Economy, Any Books Pvt. Ltd.

C.Jeevandam (2006), 'International Economy', Sultan Chand and Sons, New Delhi.

Socio economic Abstract of Sangli District, 20062007.

\section{Agricultural Productivity in Sangli District:}

Table No.1: Agricultural Productivity; Sangli District (average yield) (Yield in K.G./hector)

\begin{tabular}{|c|l|c|c|}
\hline Sr. no. & Crop Type & $\begin{array}{c}\text { Average } \\
\text { yield } \\
\mathbf{2 0 0 6 - 0 7}\end{array}$ & $\begin{array}{c}\text { Average yield } \\
\mathbf{2 0 1 6 - 1 7}\end{array}$ \\
\hline 1 & Rice & 1597 & 2555 \\
\hline 2 & Wheat & 1601 & 2483 \\
\hline 3 & $\begin{array}{l}\text { Food } \\
\text { grains }\end{array}$ & 719 & 1168 \\
\hline 4 & Pulses & 614 & 677 \\
\hline 5 & Cereals & 742 & 1264 \\
\hline 6 & Oilseeds & 1601 & 1853 \\
\hline 7 & Sugarcane & 93 & 108 \\
\hline 8 & Gram & 646 & 833 \\
\hline 9 & Cotton & 200 & 529 \\
\hline
\end{tabular}

Source: Socio-economic abstract of Sangli district, 2007 and 2017. 